\title{
PENERAPAN DATA MINING DALAM MENGELOMPOKKAN DATA RIWAYAT AKADEMIK SEBELUM KULIAH DAN DATA KELULUSAN MAHASISWA MENGGUNAKAN METODE AGGLOMERATIVE HIERARCHICAL CLUSTERING
}

(Implementation Of Data Mining In Grouping Academic History Data Before Students And Student Graduation Data Using Method Agglomerative Hierarchical Clustering)

\author{
Banu Harli Trimulya Suandi As*, Lisna Zahrotun \\ Dept Informatics Engineering, Ahmad Dahlan University \\ Jl. Ring Road Selatan, Tamanan, Banguntapan, Bantul Yogyakarta, INDONESIA \\ Email: banuharlitrimulya@gmail.com, lisna.zahrotun@tif.uad.ac.id
}

\begin{abstract}
The process of admitting new students at the Faculty of Industrial Technology, Ahmad Dahlan University, which has a very high number of students entering at the time of admission and graduating students who graduate on time is still low, causing an imbalance between the ratio of lecturers and students to be large. The number of students using campus facilities exceeds the capacity, and teaching and learning activities become ineffective. This study uses the hierarchical clustering method. The stages in this research are from Load Data, Data Cleaning, Data Transformation with One Hot Encoding method, Euclidean Distance, grouping Agglomerative Hierarchical Clustering. Results testing Cluster using the Silhouette Coefficient, was also carried out evaluation of patterns, and representation of knowledge. The study resulted in 158 recommended student data and all of them came from the island of Java and the average math score was $>=80$ on the dataset Informatics, Industry and Electrical, and $>=67$ for Chemistry. Obtained the recommended data with the number of data, respectively 43, 24, 19, and 72 data. The test method Silhouette Coefficient obtained very good results with the value Silhouette Coefficient according to the study program respectively of $0.868,0.883,0.879$, and 0.873 .
\end{abstract}

Keywords: Agglomerative Hierarchical Clustering, Clustering, Student Data, Data mining, Silhouette Coefficient

*Penulis Korespondensi

\section{Pendahuluan}

Data akademik mahasiswa merupakan data yang dihimpun dari hasil kegiatan proses belajar mengajar selama mengikuti studi di suatu perguruan tinggi. Data tersebut antara lain: data pribadi mahasiswa, data rencana studi, dan data hasil studi (nilai dan indeks prestasi) [1]. Data akademik mahasiswa ini juga berupa data penerimaan mahasiswa baru yang rutin dilakukan seluruh perguruan tinggi di Indonesia pada setiap tahunnya.

Universitas Ahmad Dahlan merupakan salah satu perguruan tinggi swasta di Indonesia yang terletak di Yogyakarta, yang terdiri dari 11 fakultas dan 34 program studi. Fakultas Teknologi Indutri (FTI) merupakan salah satunya yang memiliki 4 program studi yaitu teknik informatika, teknik industri, teknik elektro, dan teknik kimia. Penerimaan mahasiswa baru (PMB) yang dilakukan oleh FTI pada tahun 2019 terdapat 3.198 pendaftar dengan jumlah mahasiswa yang diterima berjumlah 950 mahasiswa yang sudah registrasi. Tabel 1 menunjukkan jumlah data statistik kelulusan mahasiswa FTI yang menyelesaikan kuliah tepat waktu yang bersumber dari website fakultas [2].

TABEL I. MAHASISWA LULUS TEPAT WAKTU

\begin{tabular}{|l|l|l|l|l|}
\hline No & $\begin{array}{l}\text { Jumlah } \\
\text { Mahasiswa }\end{array}$ & Tahun & $\begin{array}{l}\text { Lulus Tepat } \\
\text { Waktu }\end{array}$ & $\%$ \\
\hline 1 & 360 & 2012 & 14 & 4 \\
\hline 2 & 340 & 2013 & 22 & 6 \\
\hline 3 & 591 & 2014 & 55 & 9 \\
\hline 4 & 837 & 2015 & 181 & 22 \\
\hline
\end{tabular}

Dengan jumlah data pada Tabel I dapat dilihat dari tahun ke tahun memiliki perkembangan yang sangat cepat. Dengan jumlah mahasiswa yang masuk pada saat penerimaan mahasiswa baru yang sangat 
tinggi dan kelulusan mahasiswa tepat waktu masih rendah, menyebabkan tidak seimbang menyebabkan rasio dosen dan mahasiswa menjadi besar. Jumlah mahasiswa yang menggunakan fasilitas kampus melebihi kapasitas, dan kegiatan belajar mengajar menjadi tidak efektif.

Pengolahan data mahasiswa yang dilakukan hanya sebatas analisis statistik pada lulusan tanpa melihat data akademik sebelum kuliah. Hal ini menyebabkan belum dapat mengetahui penyebab mahasiswa lulus tidak tepat waktu. Evaluasi standar mahasiswa dan lulusan, ditentukan oleh rekrutmen mahasiswa baru dan lama studi [3].

Penelitian untuk mengetahui kelompok-kelompok data penerimaan mahasiswa baru, di mana dalam penelitian ini berhasil memetakan data mahasiswa baru menggunakan metode $K$-Means [4]. Penelitian terkait pengelompokan yang lain yaitu menggunakan metode $A H C$ untuk pengelompokan skripsi mahasiswa [5]. Penelitian memperkenalkan algoritma clustering berbasis hierarki yang menawarkan beberapa kelebihan diantaranya tidak terpengaruh adanya outlier dan dapat mendeteksi jumlah cluster yang tepat [6].

\section{TINJAUAN PUSTAKA}

Penelitian yang dilakukan sebelumnya oleh Helilintar dkk tahun 2018. Penelitian tentang penerapan metode $k$-means clustering pada data penerimaan mahasiswa baru. Dengan menggunakan variabel : Nilai UAN, Asal sekolah dan Prodi. Cluster yang dibuat berjumlah dua cluster $(\mathrm{k}=2)$. Hasil KMeans clustering yang diperoleh ada dua kelompok atau cluster, cluster pertama jika calon mahasiswa berasal dari sekolah SMA maka rata-rata yang diambil adalah prodi sistem informasi, dan cluster kedua jika calon mahasiswa berasal dari sekolah SMK maka ratarata yang diambil adalah teknik informatika [7].

Penelitian Suprawoto tahun 2016, tentang klasifikasi data mahasiswa menggunakan metode $k$ means untuk menunjang pemilihan strategi pemasaran. Dengan menggunakan variabel : nama mahasiswa, jurusan SLTA, nilai UAN, kota asal mahasiswa, IPK dan program studi yang dipilih. Jumlah cluster yang digunakan dalam penelitian ini yaitu tiga cluster $(\mathrm{k}=3)$. Berdasarkan penelitian untuk mengelompokkan mahasiswa berdasarkan nilai UN dan IPK. Menghasilkan pengelompokan jenjang pendidikan D3 dan jenjang S1. Dan dari data yang dilatih, didapatkan tiga kelompok/cluster di setiap jenjangnya [1].
Penelitian Palumpun \& Alam tahun 2017, tentang algoritma K-Means untuk pengelompokan tingkat kelulusan mahasiswa di Sains dan Teknologi Jayapura. Pengelompokan data kelulusan berdasarkan atribut IPK, lama studi, dan program studi dengan 3 cluster. Dari cluster-cluster tersebut terdapat lulusan yang memiliki lama studi kurang dari tepat waktu (5-6 tahun) memiliki IPK dan kelompok baik (3.01-3.50). Lulusan yang memiliki lama studi tidak tepat waktu (67 tahun) memiliki IPK dalam kelompok cukup (2.002.75) sampai dengan cukup baik (2.76-3.00). Sedangkan lulusan yang memiliki lama studi tepat waktu (3-4,5 tahun) memiliki IPK kelompok baik (3.013.50) dan sangat baik (>3.50) [8].

Penelitian Rosmini dkk tahun 2018, tentang implementasi metode $k$-means dalam pemetaan kelompok mahasiswa melalui data aktivitas kuliah. Dengan menggunakan variabel : IPK, Presensi, Tanggungan Biaya Kuliah, Organisasi Kampus, Pekerjaan, dan Status. Jumlah cluster yang digunakan dalam penelitian ini yaitu dua cluster $(k=2)$ menggunakan metode $k$-means clustering, cluster $A$ adalah mahasiswa yang lulus tepat waktu sedangkan cluster B adalah mahasiswa yang lulusnya tidak tepat waktu. Data pengelompokan mahasiswa ini merupakan masukan bagi dosen wali dalam membimbing dan mengawasi proses belajar mahasiswa agar bisa lulus tepat waktu [9].

Penelitian Februariyanti \& Santoso tahun 2017, tentang hierarchical agglomerative clustering untuk pengelompokan skripsi mahasiswa dengan menggunakan judul skripsi sebagai variable. Jumlah cluster yang dihasilkan yaitu lima cluster $(\mathrm{k}=5)$. Hasil pengelompokan judul skripsi mendapatkan lima topik yang paling banyak diambil oleh mahasiswa untuk skripsi. Untuk skripsi di asumsikan topiknya adalah irisan dari masing-masing data pada setiap cluster diantaranya : Sistem Informasi, Sistem Informasi Semarang, Sistem pakar berbasis web, Sistem pakar diagnosa penyakit pada tanaman, dan Rancang bangun perangkat ajar anak berbasis [5].

\section{Metode Penelitian}

Dengan menggunakan data yang dihimpun melalui studi pustaka dan wawancara dengan narasumber, maka akan dilakukan pengelompokan mahasiswa lulus tepat waktu pada mahasiswa Fakultas Teknologi Industri dengan menggunakan metode agglomerative hierarchical clustering. Adapun metodologi yang digunakan dalam penelitian seperti terdapat pada Gambar 1. 


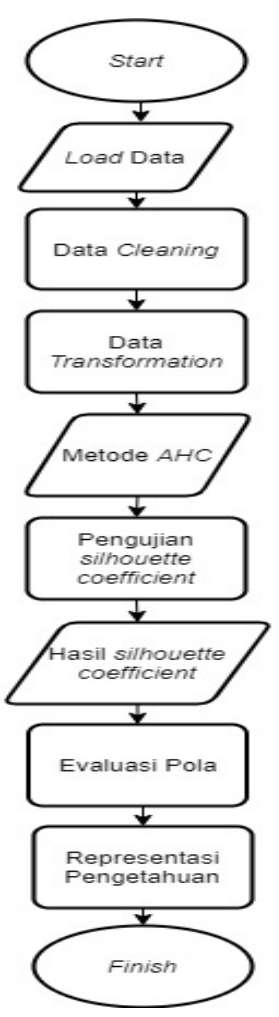

Gambar 1. Metodologi Penelitian

\subsection{Load Data}

Proses load data awal pada tahapan ini, data dikumpulkan berupa file Ms. excel yang kemudian di load ke dalam program yang akan diolah.

\subsection{Data Cleaning}

Melakukan pembersihan data riwayat sebelum kuliah dan data kelulusan, yaitu menghilangkan noise dan data yang tidak relevan. Misalnya menghapus data yang belum memiliki kelulusan atau data yang bukan mendaftar melalui jalur PMDK-Raport dan tidak berhubungan dengan variabel yang akan digunakan.

\subsection{Data Transformation}

Transformasi data dapat berupa mengonversikan tipe data, membersihkan data dengan menghapus data nol atau duplikat, memperkaya data, atau melakukan agregasi. Transformasi data yang dilakukan yaitu asal sekolah, rata-rata Matematika, provinsi sekolah, lama studi, IPK, dan TOEFL.

\subsection{Proses Pengelompokan Metode $A H C$}

Melakukan tahap $A H C$ yaitu mengelompokkan setiap obyek ke dalam kelompok/ cluster. Sehingga menemukan pasangan data paling mirip dimasukkan ke dalam cluster yang sama untuk melihat kemiripan data. Selanjutnya menggabungkan kedua obyek ke dalam satu cluster. Ulangi proses ini sampai tersisa hanya satu cluster.

\subsection{Pengujian Silhouette Coefficient}

Setelah sistem selesai dibuat maka tahapan selanjutnya adalah pengujian terhadap sistem. Pengujian ini bertujuan untuk menguji apakah sistem sudah berjalan sesuai keinginan atau belum. Pengujian terhadap sistem, dilakukan dengan metode Agglomerative hierarchical clustering. Pengujian dilakukan dengan menggunakan silhouette coefficient.

\subsection{Hasil Pengujian Silhouette Coefficient}

Dari hasil pengujian akan menghasilkan kelompok cluster terbaik berdasarkan masing-masing data cluster yang telah diuji. Data cluster dengan hasil nilai data tertinggi yang akan diterapkan menjadi kelompok data mahasiswa yang terbaik berdasarkan hasil pengujian.

\subsection{Evaluasi Pola}

Pola yang dihasilkan dari proses data mining menggunakan metode $A H C$ perlu menampilkan sebuah bentuk informasi yang mudah dimengerti oleh pihak terkait agar menjadi pengetahuan dasar yang ditemukan.

\subsection{Representasi Pengetahuan}

Setelah didapatkan hasil visualisasi kemudian dilakukan analisis untuk dapat dimengerti oleh pihak terkait sebagai pengetahuan baru.

\section{Hasil dan Pembahasan}

\subsection{Pengumpulan Data}

Data yang digunakan dalam penelitian ini adalah data mahasiswa Fakultas Teknologi Industri Universitas Ahmad Dahlan tahun angkatan 2014 dan 2015 yang diterima melalui jalur PMDK-Raport dan telah dinyatakan lulus. Data diperoleh dari Kantor Tata Usaha FTI UAD dengan jumlah data 283 data. Berikut dataset mahasiswa FTI angkatan 2014 dan 2015 dapat dilihat pada Tabel II.

Variabel data mahasiswa yang akan digunakan dalam proses data mining adalah sebagai berikut:

a. Asal Sekolah

Variabel Asal Sekolah berisi jenis sekolah yang ditempuh mahasiswa dengan kategori SMA, SMK dan MA. 
TABEL II. DATASET MAHASISWA FTI

\begin{tabular}{|l|l|l|l|l|l|l|}
\hline NIM & Sekolah & Asal Provinsi & $\begin{array}{l}\text { Rata } \\
\text { MTK }\end{array}$ & $\begin{array}{l}\text { Lama } \\
\text { Studi } \\
\text { (Hari) }\end{array}$ & IPK & TOEFL \\
\hline 1400018012 & SMA & DI Yogyakarta & 83,33 & 1135 & 3,46 & 460 \\
\hline 1400018017 & SMA & Jawa Barat & 89,33 & 1463 & 3,57 & 406 \\
\hline 1400018026 & SMK & Jawa Barat & 78,33 & 1825 & 2,68 & 403 \\
\hline 1400018041 & SMA & $\begin{array}{l}\text { Sulawesi } \\
\text { Tengah }\end{array}$ & 79 & 1463 & 3,63 & 400 \\
\hline 1400018051 & SMA & Riau & 78 & 1478 & 3,56 & 433 \\
\hline 1400018067 & SMA & $\begin{array}{l}\text { Nusa } \\
\text { Tenggara } \\
\text { Barat }\end{array}$ & 89,33 & 1492 & 3,06 & 400 \\
\hline 1400018070 & SMK & DI Yogyakarta & 83 & 1460 & 3,65 & 416 \\
\hline 1400018082 & SMK & DI Yogyakarta & 87,33 & 1478 & 3,00 & 400 \\
\hline$\ldots$. & $\ldots . .$. & \multicolumn{1}{c|}{$\ldots . .}$. & $\ldots$. & $\ldots$. & $\ldots$. \\
\hline 1500022083 & SMK & Jawa Tengah & 76 & 1135 & 3,65 & 406 \\
\hline
\end{tabular}

\section{b. Asal Provinsi}

Variabel Asal provinsi berisi asal provinsi mahasiswa. Provinsi - provinsi tersebut dibagi menjadi 3 Wilayah yang berdasarkan pada perhitungan kualitas pendidikan di wilayah Indonesia menggunakan metode $K$-Means [10].

\section{c. Rata MTK}

Variabel Rata MTK adalah nilai rata - rata matematika mahasiswa saat melakukan pendaftaran masuk Universitas dari jalur PMDK-Raport.

d. Lama masa studi

Variabel lama masa studi menentukan apakah mahasiswa lulus dengan Tepat Waktu atau Tidak. Setelah melakukan wawancara dengan pihak Tata Usaha Fakultas menyatakan bahwa, Mahasiswa dikatakan lulus tepat waktu jika lama masa studi yang ditempuh adalah $<=4$ tahun dan jika $>4$ tahun maka tidak tepat waktu.

e. IPK

IPK adalah Indeks Prestasi Komulatif yang didapat setelah lulus kuliah.

f. TOEFL

Merupakan salah satu syarat kelulusan bagi mahasiswa tingkat akhir.

\subsection{Pengujian Algoritma}

Pengujian algoritma dilakukan dengan mengambil 10 data sampel dengan menggunakan metode Agglomerative hierarchical clustering. Dataset yang digunakan yaitu Prodi Informatika dapat dilihat pada Tabel III.

Pada tahap transformasi data, berupa proses konversi dari data ke sumber tujuan yang sudah ditetapkan. Transformasi yang akan dilakukan adalah mentransformasikan asal sekolah, dan asal provinsi menggunakan metode One Hot Encoding. Metode transformasi ini menggunakan angka biner sebagai value dari atribut atau data yang akan di transformasi [11].
TABEL III. DATASET PENGUJIAN

\begin{tabular}{|l|l|l|l|l|l|l|}
\hline NIM & Sekolah & Asal Provinsi & $\begin{array}{l}\text { Rata } \\
\text { MTK }\end{array}$ & $\begin{array}{l}\text { Lama } \\
\text { Studi } \\
\text { (Hari) }\end{array}$ & IPK & TOEFL \\
\hline 1400018012 & SMA & DI Yogyakarta & 83,33 & 1135 & 3,46 & 460 \\
\hline 1400018017 & SMA & Jawa Barat & 89,33 & 1463 & 3,57 & 406 \\
\hline 1400018026 & SMK & Jawa Barat & 78,33 & 1825 & 2,68 & 403 \\
\hline 1400018041 & SMA & $\begin{array}{l}\text { Sulawesi } \\
\text { Tengah }\end{array}$ & 79 & 1463 & 3,63 & 400 \\
\hline 1400018051 & SMA & Riau & 78 & 1478 & 3,56 & 433 \\
\hline 1400018067 & SMA & $\begin{array}{l}\text { Nusa } \\
\text { Tenggara } \\
\text { Barat }\end{array}$ & 89,33 & 1492 & 3,06 & 400 \\
\hline 1400018070 & SMK & DI Yogyakarta & 83 & 1460 & 3,65 & 416 \\
\hline 1400018082 & SMK & DI Yogyakarta & 87,33 & 1478 & 3,00 & 400 \\
\hline 1400018084 & SMA & $\begin{array}{l}\text { Sumatera } \\
\text { Selatan }\end{array}$ & 84,33 & 1478 & 3,20 & 446 \\
\hline 1400018092 & SMK & Jawa Timur & 76,66 & 1478 & 3,16 & 430 \\
\hline
\end{tabular}

1. Asal Sekolah

TABEL IV. TRANSFORMASI ASAL SEKOLAH

\begin{tabular}{|l|l|l|l|l|}
\hline NIM & Sekolah & MA & SMA & SMK \\
\hline 1400018012 & SMA & 0 & 1 & 0 \\
\hline 1400018017 & SMA & 0 & 1 & 0 \\
\hline 1400018026 & SMK & 0 & 0 & 1 \\
\hline 1400018041 & SMA & 0 & 1 & 0 \\
\hline 1400018051 & SMA & 0 & 1 & 0 \\
\hline 1400018067 & SMA & 0 & 1 & 0 \\
\hline 1400018070 & SMK & 0 & 0 & 1 \\
\hline 1400018082 & SMK & 0 & 0 & 1 \\
\hline 1400018084 & SMA & 0 & 1 & 0 \\
\hline 1400018092 & SMK & 0 & 0 & 1 \\
\hline
\end{tabular}

2. Asal Provinsi

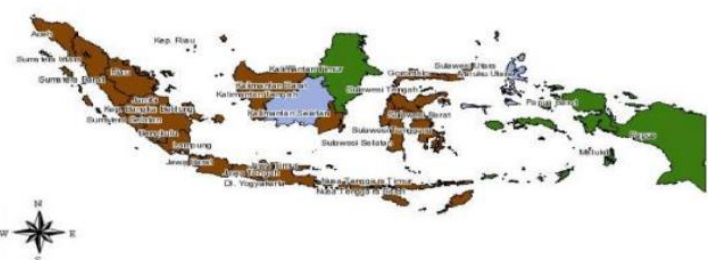

Gambar 2. Pemetaan Kualitas Pendidikan di Indonesia [10]

Pengelompokan ini berdasarkan tingkat kualitas pendidikan dengan parameter tertentu yang sudah diteliti [10].

TABEL V. TRANSFORMASI WILAYAH

\begin{tabular}{|l|l|l|}
\hline Wilayah & Warna Peta & Provinsi \\
\hline Wilayah 1 & Abu-abu & $\begin{array}{l}\text { Maluku Utara dan Kalimantan } \\
\text { Tengah. }\end{array}$ \\
\hline Wilayah 2 & Coklat & $\begin{array}{l}\text { Aceh, Sumatra Barat, Sumatra } \\
\text { Utara, Sumatra Selatan, Riau, } \\
\text { Kepulauan Riau, Jambi, Bengkulu, } \\
\end{array}$ \\
& $\begin{array}{l}\text { Kepulauan Bangka Belitung, } \\
\text { Lampung, Banten, DKI Jakarta, } \\
\text { Jawa Barat, Jawa Tengah, Jawa }\end{array}$ \\
\hline
\end{tabular}




\begin{tabular}{|c|c|c|}
\hline & & $\begin{array}{l}\text { Timur, DI Yogyakarta, Bali, NTB, } \\
\text { NTT, Kalimantan Barat, } \\
\text { Kalimantan Selatan, Gorontalo, } \\
\text { Sulawesi Barat, Sulawesi Selatan, } \\
\text { Sulawesi Tenggara, Sulawesi } \\
\text { Tenggara, dan Sulawesi Utara. }\end{array}$ \\
\hline Wilayah 3 & Hijau & $\begin{array}{l}\text { Papua, Papua Barat, Kalimantan } \\
\text { Timur, dan Maluku. }\end{array}$ \\
\hline
\end{tabular}

TABEL VI. TRANSFORMASI ASAL PROVINSI

\begin{tabular}{|l|l|l|l|l|}
\hline NIM & $\begin{array}{l}\text { Asal } \\
\text { Provinsi }\end{array}$ & $\begin{array}{l}\text { Wilayah } \\
1\end{array}$ & $\begin{array}{l}\text { Wilayah } \\
2\end{array}$ & $\begin{array}{l}\text { Wilayah } \\
3\end{array}$ \\
\hline 1400018012 & $\begin{array}{l}\text { DI } \\
\text { Yogyakarta }\end{array}$ & 0 & 1 & 0 \\
\hline 1400018017 & Jawa Barat & 0 & 1 & 0 \\
\hline 1400018026 & Jawa Barat & 0 & 1 & 0 \\
\hline 1400018041 & $\begin{array}{l}\text { Sulawesi } \\
\text { Tengah }\end{array}$ & 0 & 1 & 0 \\
\hline 1400018051 & Riau & 0 & 1 & 0 \\
\hline 1400018067 & $\begin{array}{l}\text { Nusa } \\
\text { Tenggara } \\
\text { Barat }\end{array}$ & 0 & 1 & 0 \\
\hline 1400018070 & $\begin{array}{l}\text { DI } \\
\text { Yogyakarta }\end{array}$ & 0 & 1 & 0 \\
\hline 1400018082 & $\begin{array}{l}\text { DI } \\
\text { Yogyakarta }\end{array}$ & 0 & 1 & 0 \\
\hline 1400018084 & $\begin{array}{l}\text { Sumatera } \\
\text { Selatan }\end{array}$ & 0 & 1 & 0 \\
\hline 1400018092 & $\begin{array}{l}\text { Jawa } \\
\text { Timur }\end{array}$ & 0 & 1 & 0 \\
\hline
\end{tabular}

Berikut merupakan transformasi keseluruhan dataset pengujian.

TABEL VII. TRANSFormasi Dataset PENGUJIAN

\begin{tabular}{|l|l|l|l|l|l|l|l|}
\hline NIM & $\begin{array}{l}\text { S } \\
\text { M }\end{array}$ & $\begin{array}{l}\text { S } \\
\text { M } \\
\text { K }\end{array}$ & $\begin{array}{l}\text { Wilayah } \\
\text { K }\end{array}$ & $\begin{array}{l}\text { Rata } \\
\text { MTK }\end{array}$ & $\begin{array}{l}\text { Lama } \\
\text { Studi } \\
\text { (Hari) }\end{array}$ & IPK & TOEFL \\
\hline 1400018012 & 1 & 0 & 1 & 83,33 & 1135 & 3,46 & 460 \\
\hline 1400018017 & 1 & 0 & 1 & 89,33 & 1463 & 3,57 & 406 \\
\hline 1400018026 & 0 & 1 & 1 & 78,33 & 1825 & 2,68 & 403 \\
\hline 1400018041 & 1 & 0 & 1 & 79 & 1463 & 3,63 & 400 \\
\hline 1400018051 & 1 & 0 & 1 & 78 & 1478 & 3,56 & 433 \\
\hline 1400018067 & 1 & 0 & 1 & 89,33 & 1492 & 3,06 & 400 \\
\hline 1400018070 & 0 & 1 & 1 & 83 & 1460 & 3,65 & 416 \\
\hline 1400018082 & 0 & 1 & 1 & 87,33 & 1478 & 3,00 & 400 \\
\hline 1400018084 & 1 & 0 & 1 & 84,33 & 1478 & 3,20 & 446 \\
\hline 1400018092 & 0 & 1 & 1 & 76,66 & 1478 & 3,16 & 430 \\
\hline
\end{tabular}

Tahapan selanjutnya menghitung Euclidean Distance digunakan untuk mengukur jarak terdekat pada setiap data mahasiswa. Dikatakan jarak terdekat adalah nilai jarak Euclidean yang paling kecil atau nilai yang mendekati 0 .

\section{Rumus Euclidean Distance}

$$
|| \mathrm{U}-\mathrm{V}||=\sqrt{\sum i(\mathrm{Ui}-\mathrm{Vi})^{2}}
$$

$$
\mathrm{V}_{\mathrm{i}}=\text { nilai } \mathrm{V} \text { pada data uji }
$$

Menghitung jarak euclidean pada setiap mahasiswa, seperti pada 2 sampel perhitungan berikut :

a. Menghitung MHS $1-$ MHS 2 :

$$
\begin{aligned}
& \sqrt{\begin{array}{c}
(0-0)^{2}+(1-1)^{2}+(0-0)^{2}+(83,33-89,33)^{2}+(1135-1463)^{2}+ \\
(3,46-3,57)^{2}+(460-406)^{2}+(0-0)^{2}+(1-1)^{2}+(0-0)^{2}
\end{array}} \\
& =\sqrt{0+0+0+36+107584+0,012+2916+} \\
& \quad 0+0+0
\end{aligned}
$$

b. Menghitung MHS $1-\mathrm{MHS} 3$ :

$$
\begin{aligned}
& \sqrt{\begin{array}{c}
(0-0)^{2}+(1-1)^{2}+(0-0)^{2}+(83,33-78,33)^{2}+(1135-1825)^{2}+ \\
(3,46-2,68)^{2}+(460-403)^{2}+(0-0)^{2}+(1-0)^{2}+(0-1)^{2}
\end{array}} \\
& =\sqrt{\begin{array}{c}
0+0+0+25+476100+0,608+3249+ \\
0+1+1
\end{array}} \\
& =\sqrt{479.376,608}=692.37
\end{aligned}
$$

Jarak euclidean dihitung untuk seluruh data, dilakukan seperti perhitungan pada rumus Persamaan (1) seperti pada contoh.

TABEL VIII. HASIL PERHItungan EuCLIDEAN Distance

\begin{tabular}{|c|c|c|c|c|c|c|c|c|c|c|}
\hline \multicolumn{10}{|c|}{ EUCLIDEAN DISTANCE } \\
\hline Data & mhs 1 & mhs 2 & mhs 3 & mhs 4 & mhs 5 & mhs 6 & mhs 7 & mhs 8 & mhs 9 & mhs 10 \\
\hline mhs 1 & 0 & 332,47 & 692,37 & 333,47 & 344,1 & 362,05 & 327,97 & 348,23 & 342,29 & 344,38 \\
\hline mhs 2 & 332,47 & 0 & 362,18 & 11,95 & 32,9 & 29,62 & 12,29 & 16,35 & 44,12 & 31,04 \\
\hline mhs 3 & 692,37 & 362,18 & 0 & 362,02 & 348,3 & 362,2 & 365,27 & 362,12 & 349,71 & 348,05 \\
\hline mhs 4 & 333,47 & 11,95 & 362,02 & 0 & 32,26 & 30,79 & 16,82 & 17,17 & 48,68 & 33,65 \\
\hline mhs 5 & 344,1 & 32,9 & 348,3 & 32,26 & 0 & 37,6 & 25,3 & 34,32 & 14,46 & 3,6 \\
\hline mhs 6 & 362,05 & 29,62 & 362,2 & 30,79 & 37,6 & 0 & 36,37 & 14,21 & 48,34 & 35,47 \\
\hline mhs 7 & 327,97 & 12,29 & 365,27 & 16,82 & 25,3 & 36,37 & 0 & 24,48 & 35,04 & 23,67 \\
\hline mhs 8 & 348,23 & 16,35 & 362,12 & 17,17 & 34,32 & 14,21 & 24,48 & 0 & 46,11 & 10,66 \\
\hline mhs 9 & 342,29 & 44,12 & 349,71 & 48,68 & 14,46 & 48,34 & 35,04 & 46,11 & 0 & 17,8 \\
\hline mhs 10 & 344,38 & 31,04 & 348,05 & 33,65 & 3,6 & 35,47 & 23,67 & 10,66 & 17,8 & 0 \\
\hline
\end{tabular}

Berdasarkan matrik jarak, selanjutnya dilakukan pengelompokan data dengan Agglomerative Hierarchical Clustering $(A H C)$ menggunakan metode yaitu single linkage pada Persamaan (2).

$$
d_{\text {data }}=\min \left\{d_{\text {data }}\right\}, d_{\text {data }} \in D
$$

\section{dimana :}

$d_{\text {data }}=$ jarak antara tetangga terdekat/terkecil dari kelompok data

$D=$ matriks kedekatan jarak Euclidean

Dengan menganggap data sebagai kelompok, selanjutnya memilih jarak dua kelompok yang terkecil terdapat pada Tabel IX.

$$
\min \left(d_{\text {data }}\right)=\min \left(d_{\text {mhs } 5, \text { mhs10 }}\right)=3,6
$$

dimana:

$\mathrm{U}_{\mathrm{i}}=$ nilai $\mathrm{U}$ pada data latih 
TABEL IX. TAHAPAN 1 SINGLE LINKAGE

\begin{tabular}{|c|c|c|c|c|c|c|c|c|c|c|}
\hline Data & mhs 1 & mhs 2 & mhs 3 & mhs 4 & mhs 5 & mhs 6 & mhs 7 & mhs 8 & mhs 9 & mhs 10 \\
\hline mhs 1 & 0 & 332,47 & 692,37 & 333,47 & 344,1 & 362,05 & 327,97 & 348,23 & 342,29 & 344,38 \\
\hline mhs 2 & 332,47 & 0 & 362,18 & 11,95 & 32,9 & 29,62 & 12,29 & 16,35 & 44,12 & 31,04 \\
\hline mhs 3 & 692,37 & 362,18 & 0 & 362,02 & 348,3 & 362,2 & 365,27 & 362,12 & 349,71 & 348,05 \\
\hline mhs 4 & 333,47 & 11,95 & 362,02 & 0 & 32,26 & 30,79 & 16,82 & 17,17 & 48,68 & 33,65 \\
\hline mhs 5 & 344,1 & 32,9 & 348,3 & 32,26 & 0 & 37,6 & 25,3 & 34,32 & 14,46 & 3,6 \\
\hline mhs 6 & 362,05 & 29,62 & 362,2 & 30,79 & 37,6 & 0 & 36,37 & 14,21 & 48,34 & 35,47 \\
\hline mhs 7 & 327,97 & 12,29 & 365,27 & 16,82 & 25,3 & 36,37 & 0 & 24,48 & 35,04 & 23,67 \\
\hline mhs 8 & 348,23 & 16,35 & 362,12 & 17,17 & 34,32 & 14,21 & 24,48 & 0 & 46,11 & 10,66 \\
\hline mhs 9 & 342,29 & 44,12 & 349,71 & 48,68 & 14,46 & 48,34 & 35,04 & 46,11 & 0 & 17,8 \\
\hline mhs 10 & 344,38 & 31,04 & 348,05 & 33,65 & 3,6 & 35,47 & 23,67 & 10,66 & 17,8 & 0 \\
\hline
\end{tabular}

Tahapan selanjutnya dipilih jarak terkecil dari kelompok untuk menghitung jarak antara kelompok mhs 5 dan mhs 10 dengan kelompok lain yang masih tersisa yaitu, mhs 1 , mhs 2 , mhs 3 , mhs 4 , mhs 6 , mhs 7, mhs 8 , dan mhs 9. Dengan menghapus baris-baris dan kolom-kolom matrik pada kelompok mhs 5 dan mhs 10, serta menambahkan baris dan kolom untuk kelompok (mhs 5, mhs 10). Hasil proses pengelompokan tahap 1 dapat dilihat pada Tabel IX. Dengan menganggap data sebagai kelompok, selanjutnya memilih jarak dua kelompok yang terkecil terdapat pada Tabel $\mathrm{X}$.

$\min \left(d_{\text {data }}\right)=\min \left(d_{\text {mhs5, }}\right.$ mss10,mhs $)=10,66$

TABEL X. TAHAPAN 2 SINGLE LINKAGE

\begin{tabular}{|c|c|c|c|c|c|c|c|c|c|}
\hline Data & mhs 5, mhs 10 & mhs 1 & mhs 2 & mhs 3 & mhs 4 & mhs 6 & mhs 7 & mhs 8 & mhs 9 \\
\hline mhs 5, mhs 10 & 0 & 344,1 & 31,04 & 348,05 & 32,26 & 35,47 & 23,67 & 10,66 & 14,46 \\
\hline mhs 1 & 344,1 & 0 & 332,47 & 692,37 & 333,47 & 362,05 & 327,97 & 348,23 & 342,29 \\
\hline mhs 2 & 31,04 & 332,47 & 0 & 362,18 & 11,95 & 29,62 & 12,29 & 16,35 & 44,12 \\
\hline mhs 3 & 348,05 & 692,37 & 362,18 & 0 & 362,02 & 362,2 & 365,27 & 362,12 & 349,71 \\
\hline mhs 4 & 32,26 & 333,47 & 11,95 & 362,02 & 0 & 30,79 & 16,82 & 17,17 & 48,68 \\
\hline mhs 6 & 35,47 & 362,05 & 29,62 & 362,2 & 30,79 & 0 & 36,37 & 14,21 & 48,34 \\
\hline mhs 7 & 23,67 & 327,97 & 12,29 & 365,27 & 16,82 & 36,37 & 0 & 24,48 & 35,04 \\
\hline mhs 8 & 10,66 & 348,23 & 16,35 & 362,12 & 17,17 & 14,21 & 24,48 & 0 & 46,11 \\
\hline mhs 9 & 14,46 & 342,29 & 44,12 & 349,71 & 48,68 & 48,34 & 35,04 & 46,11 & 0 \\
\hline
\end{tabular}

Tahapan single linkage ini dilakukan sampai tersisa hanya satu cluster atau pengelompokan. Sehingga diperoleh hasil cluster atau pengelompokan yang dapat dilihat pada Tabel XI. tabel XI. hasil Cluster atau Pengelompokan

\begin{tabular}{|c|c|c|c|}
\hline Tahapan & Jumlah Cluster & Anggota & Jarak Terkecil \\
\hline 1 & 9 & mhs 5, mhs 10 & 3,6 \\
\hline 2 & 8 & mhs 5, mhs 10, mhs 8 & 10,66 \\
\hline 3 & 7 & mhs 2, mhs 4 & 11,98 \\
\hline 4 & 6 & mhs 2, mhs 4, mhs 7 & 12,29 \\
\hline 5 & 5 & mhs 5, mhs 10, mhs 8, mhs 6 & 14,21 \\
\hline 6 & 4 & $\begin{array}{c}\text { mhs 5, mhs 10, mhs 8, mhs 6, } \\
\text { mhs 9 }\end{array}$ & 14,46 \\
\hline 7 & 3 & $\begin{array}{c}\text { mhs 5, mhs 10, mhs 8, mhs 6, } \\
\text { mhs 9, mhs 2, mhs 4, mhs 7 }\end{array}$ & 17,17 \\
\hline 8 & 2 & $\begin{array}{c}\text { mhs 5, mhs 10, mhs 8, mhs 6, } \\
\text { mhs 9, mhs 2, mhs 4, mhs 7, } \\
\text { mhs 1 }\end{array}$ & 327,97 \\
\hline 9 & 1 & $\begin{array}{c}\text { mhs 5, mhs 10, mhs 8, mhs 6, } \\
\text { mhs 9, mhs 2, mhs 4, mhs 7, } \\
\text { mhs 1, mhs 3 }\end{array}$ & 348,05 \\
\hline
\end{tabular}

Selanjutnya menguji hasil cluster dengan menggunakan silhouette coefficient.

a. Menghitung nilai rata-rata jarak objek dengan dokumen yang berada dalam satu cluster dengan menggunakan Persamaan (3).

$$
a(i)=\frac{1}{[A]-1} \quad \sum j \in C d(i, j)
$$

dimana :

a(i) =Perbedaan rata-rata objek (i) ke semua objek lain pada $A$.

$d(i, j) \quad=$ Jarak antara data $i$ ke $j$.

A $=$ Cluster.

TABEL XII. HASIL PERHITUNGAN A(I)

\begin{tabular}{|c|c|c|}
\hline Data & $a(i)$ & Cluster \\
\hline mhs 1 & 341,87 & 0 \\
\hline mhs 2 & 63,84 & 0 \\
\hline mhs 3 & 444,03 & 1 \\
\hline mhs 4 & 65,60 & 0 \\
\hline mhs 5 & 109,11 & 0 \\
\hline mhs 6 & 65,57 & 0 \\
\hline mhs 7 & 62,74 & 0 \\
\hline mhs 8 & 63,94 & 0 \\
\hline mhs 9 & 74,61 & 0 \\
\hline mhs 10 & 62,53 & 0 \\
\hline
\end{tabular}

b. Menghitung jarak objek dengan dokumen antara cluster dengan menggunakan Persamaan (4) dan Persamaan (5).

$$
\begin{aligned}
& d(i, C)=\frac{1}{[A]} \quad \sum j \in C d(i, j) \\
& b(i)=\min C \neq A d(i, C)
\end{aligned}
$$

dimana :

$d(i, C)=$ Perbedaan rata-rata objek $(i)$ ke semua objek lain pada $C$.

C = Cluster lain selain cluster $\mathrm{A}$ atau cluster $\mathrm{C}$ tidak sama dengan cluster $\mathrm{A}$. 
$b(i)=$ Rara-rata jarak objek dengan semua objek lain yang berbeda pada cluster lainnya.

TABEL XIII. HASIL PERHITUNGAN D(I, C) DAN B(I)

\begin{tabular}{|c|c|c|c|}
\hline Data & $d(i, C)$ & $b(i)$ & Cluster \\
\hline mhs 1 & 76,93 & 692,37 & 0 \\
\hline mhs 2 & 40,24 & 362,18 & 0 \\
\hline mhs 3 & 0,00 & 355,22 & 1 \\
\hline mhs 4 & 40,22 & 362,02 & 0 \\
\hline mhs 5 & 38,70 & 348,30 & 0 \\
\hline mhs 6 & 40,24 & 362,20 & 0 \\
\hline mhs 7 & 40,59 & 365,27 & 0 \\
\hline mhs 8 & 40,24 & 362,12 & 0 \\
\hline mhs 9 & 38,86 & 349,71 & 0 \\
\hline mhs 10 & 38,67 & 348,05 & 0 \\
\hline
\end{tabular}

c. Kemudian menghitung nilai Silhouette Coefficient dengan menggunakan Persamaan (6).

$$
s(i)=\frac{b(i)-a(i)}{\min (a(i), b(i))}
$$

dimana :

$S(i)=$ Silhouette Coefficient

$a(i)=$ Rata-rata jarak objek dengan semua objek yang berbeda dalam satu cluster.

$b(i)=$ Rara-rata jarak objek dengan semua objek lain yang berbeda pada cluster lainnya.

TABEL XIV. Hasil Silhouette Coefficient s(i)

\begin{tabular}{|c|c|c|c|c|}
\hline Duv & $a(i)$ & $b(i)$ & $s(i)$ & Cluster \\
\hline mhs 1 & 341,87 & 692,37 & 0,51 & 0 \\
\hline mhs 2 & 63,84 & 362,18 & 0,82 & 0 \\
\hline mhs 3 & 444,03 & 355,22 & $-0,25$ & 1 \\
\hline mhs 4 & 65,60 & 362,02 & 0,82 & 0 \\
\hline mhs 5 & 109,11 & 348,30 & 0,69 & 0 \\
\hline mhs 6 & 65,57 & 362,20 & 0,82 & 0 \\
\hline mhs 7 & 62,74 & 365,27 & 0,83 & 0 \\
\hline mhs 8 & 63,94 & 362,12 & 0,82 & 0 \\
\hline mhs 9 & 74,61 & 349,71 & 0,79 & 0 \\
\hline mhs 10 & 62,53 & 348,05 & 0,82 & 0 \\
\hline
\end{tabular}

Berdasarkan hasil pengujian silhouette coefficient untuk kualitas cluster dengan jumlah sampel 10 data diperoleh dua nilai, nilai silhouette coefficient sebesar 0,83 yang artinya kualitas cluster baik dan nilai silhouette coefficient sebesar $-0,25$ yang artinya kualitas cluster kurang baik. Representasi pengetahuan dari hasil clustering yang disajikan pada Tabel XIV sebagai berikut :
1. Cluster 0 memiliki anggota sebanyak 9 data dengan rata-rata matematika 83,37 dan masa studi 1436 hari, serta dengan rata-rata IPK 3,37.

2. Cluster 1 memiliki anggota sebanyak 1 data dengan rata-rata matematika 78,33, masa studi 1825 hari, serta dengan rata-rata IPK 2,68 .

\subsection{Pengembangan Sistem}

\subsubsection{Load data}

Tahapan load data merupakan tahapan awal dalam proses data mining. Di mana, pengguna mengupload data mahasiswa FTI dalam format excel. Dataset berupa file excel yang terpisah menjadi 4 buah file dengan nama file "Informatika.xlsx", "Kimia.xIsx", "Industri.xIsx", dan "Elektro.xlsx".

Dengan menggunakan salah satu dataset yaitu dataset Program Studi Informatika, hasil dari load data dapat dilihat pada Gambar 3.

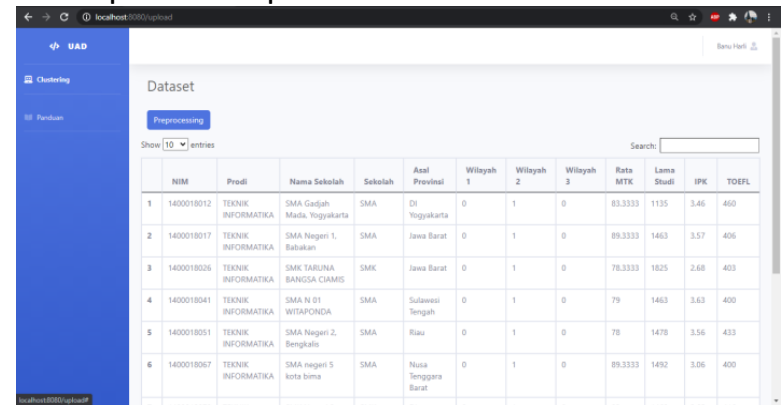

Gambar 3. Load Dataset

\subsubsection{Preprocessing data}

Cleaning atau Pembersihan Data adalah proses di mana data - data mahasiswa yang telah di load dibersihkan terlebih dahulu dari data - data noise (memiliki nilai aneh) dan data yang tidak digunakan dalam proses mining. Selanjutnya tahapan seleksi lagi untuk memutuskan variabel data yang akan digunakan dalam proses mining karena hanya data yang relevan yang diambil dari database. Setelah diseleksi data akan melalui proses transformasi. Hasil preprocessing data dapat dilihat pada Gambar 4.

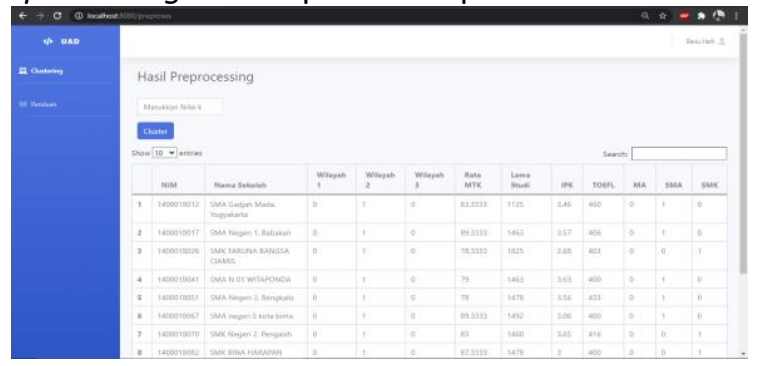

Gambar 4. Preprocessing Data 


\subsubsection{Agglomerative Hierarchical Clustering}

Tahap $A H C$ yaitu mengelompokkan setiap obyek ke dalam kelompok atau cluster. Sehingga menemukan pasangan data paling mirip dimasukkan ke dalam cluster yang sama untuk melihat kemiripan data. Hasil clustering dapat dilihat pada Gambar 5.

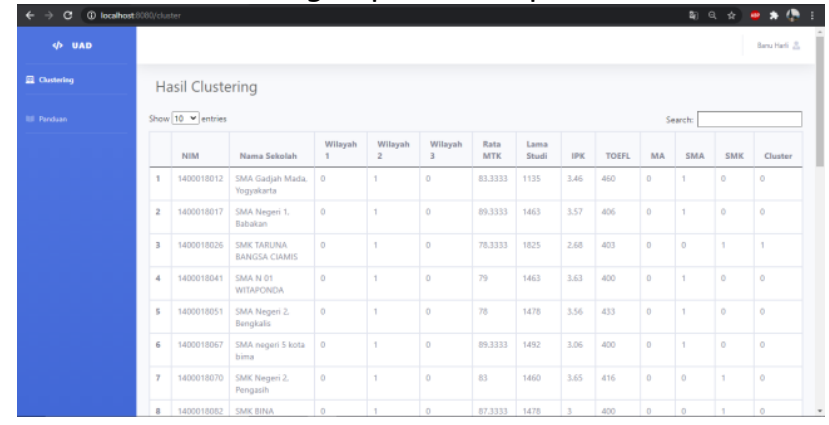

Gambar 5. Pengelompokan AHC

\subsubsection{Chart}

Chart adalah menampilkan jumlah data yang terbentuk dari hasil cluster untuk mengetahui cluster yang ada dalam pengelompokan data. Tampilan halaman chart dapat dilihat pada Gambar 6 .

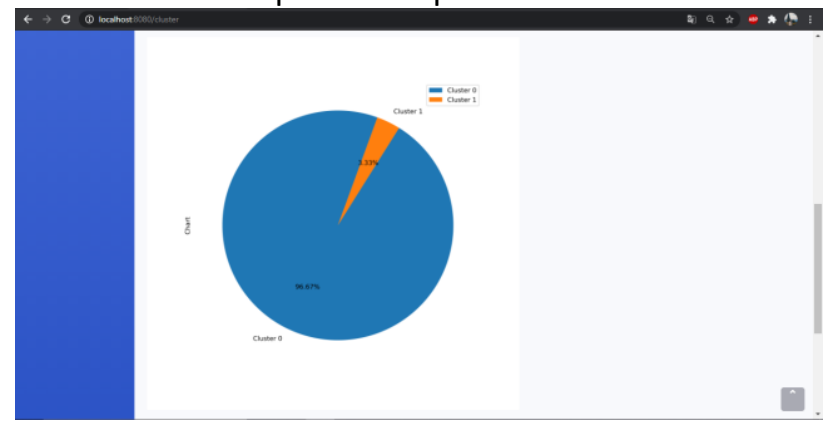

Gambar 6. Chart

\subsubsection{Pengujian}

Pengujian adalah cara untuk mengetahui seberapa baik hasil yang diperoleh dari proses clustering menggunakan silhouette coefficient. Tampilan halaman pengujian dapat dilihat pada Gambar 7.
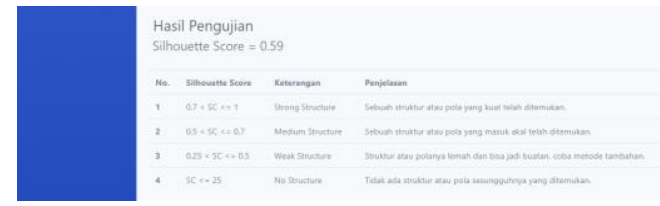

Gambar 7. Pengujian

\subsubsection{Representasi Pengetahuan}

\section{a. Dataset Informatika}

Pada dataset Informatika dengan jumlah data 90, diperoleh pengujian yang disajikan pada Tabel XV.
TABEL XV. HASIL PENGUIIAN DATASET INFORMATIKA

\begin{tabular}{|c|c|}
\hline Nilai K ( Jumlah Titik Pusat ) & Hasil Silhouette Coefficient \\
\hline 2 & 0,593 \\
\hline 3 & 0,868 \\
\hline 4 & 0,878 \\
\hline 5 & 0,861 \\
\hline 6 & 0,786 \\
\hline 7 & 0,791 \\
\hline 8 & 0,782 \\
\hline
\end{tabular}

Berdasarkan hasil pengujian pada dataset Informatika dapat ditarik kesimpulan bahwa pada dataset Informatika jumlah cluster terbaik yaitu 4 . Sehingga diperoleh 4 cluster dengan evaluasi pola setiap cluster sebagai berikut :

TABEL XVI. HASIL CLUSTER INFORMATIKA

\begin{tabular}{|c|c|c|c|c|c|c|c|c|}
\hline Nilaik & Data & Asal Sekolah & Wilayah & Pulau & Rata MTK & TOEFL & IPK & Lama Studi \\
\hline cluster 0 & 4 & SMA \& SMK & 2 & Kalimantan & 63 & 206 & 3,44 & 3Tahun 10Bulan \\
\hline cluster1 & 43 & SMA & 2 & Jawa & 80 & 424 & 3,5 & 3 Tahun 9Bulan \\
\hline cluster2 & 40 & SMA & 2 & Jawa & 82 & 428 & 3,38 & 4Tahun 3Bulan \\
\hline cluster3 & 3 & SMA & 2 & Jawa & 79 & 426 & 2,96 & 5Tahun \\
\hline
\end{tabular}

Hasil dari evaluasi pola pada dataset informatika dengan jumlah cluster 4, maka diperoleh cluster 1 sebagai cluster yang terbaik untuk rekomendasi lulus tepat waktu, jika nilai rata-rata matematika 80, berasal dari pulau Jawa, dan rata-rata IPK sebesar 3,50.

\section{b. Dataset Kimia}

Pada dataset Kimia dengan jumlah data 87, diperoleh pengujian yang disajikan pada Tabel XVII.

TABEL XVII. HASIL PENGUJIAN DATASET KIMIA

\begin{tabular}{|c|c|}
\hline Nilai K ( Jumlah Titik Pusat ) & Hasil Silhouette Coefficient \\
\hline 2 & 0,873 \\
\hline 3 & 0,819 \\
\hline 4 & 0,539 \\
\hline 5 & 0,473 \\
\hline 6 & 0,463 \\
\hline 7 & 0,446 \\
\hline 8 & 0,399 \\
\hline
\end{tabular}

Berdasarkan hasil pengujian pada dataset kimia dapat ditarik kesimpulan bahwa pada dataset kimia jumlah cluster terbaik yaitu 2. Sehingga diperoleh 2 cluster dengan evaluasi pola setiap cluster sebagai berikut :

TABEL XVIII. HASIL CLUSTER KIMIA

\begin{tabular}{|c|c|c|c|c|c|c|c|c|}
\hline Nilaik & Data & Asal Sekolahn & Wiliagh & Pulau & \begin{tabular}{|l|} 
Reta WTK \\
\end{tabular} & TOEFL & IPK & lammstudi \\
\hline clustero & 15 & SWA & 2 & Jawa & 60 & 420 & 3,33 & 4tahnn 2Bulan \\
\hline duster1 & 72 & SMA & 2 & Jawa & 67 & 438 & 3,53 & 3Tahun9Bulan \\
\hline
\end{tabular}

Hasil dari evaluasi pola pada dataset kimia dengan jumlah cluster 2, maka diperoleh cluster 1 sebagai cluster yang terbaik untuk rekomendasi lulus 
tepat waktu, jika nilai rata-rata matematika 67, berasal dari pulau Jawa, dan rata-rata IPK sebesar 3,53.

\section{c. Dataset Industri}

Pada dataset Industri dengan jumlah data 76, diperoleh pengujian yang disajikan pada Tabel XIX.

TABEL XIX. HASIL PENGUJIAN DATASET INDUSTRI

\begin{tabular}{|c|c|}
\hline Nilai K ( Jumlah Titik Pusat ) & Hasil Silhouette Coefficient \\
\hline 2 & 0,749 \\
\hline 3 & 0,625 \\
\hline 4 & 0,883 \\
\hline 5 & 0,710 \\
\hline 6 & 0,374 \\
\hline 7 & 0,404 \\
\hline 8 & 0,407 \\
\hline
\end{tabular}

Berdasarkan hasil pengujian pada dataset Industri dapat ditarik kesimpulan bahwa pada dataset Industri jumlah cluster terbaik yaitu 4. Sehingga diperoleh 4 cluster dengan evaluasi pola setiap cluster sebagai berikut :

TABEL XX. Hasil Cluster Industri

\begin{tabular}{|c|c|c|c|c|c|c|c|c|}
\hline Nilaik & Data & Asal Sekolah & Wilayah & Pulau & Rata MTK & TOEFL & IPK & Lama Studi \\
\hline cluster0 & 49 & SMA & 2 & Jawa & 75 & 428 & 3,36 & 4Tahun 2Bulan \\
\hline cluster1 & 24 & SMA & 2 & Jawa & 84 & 423 & 3,56 & 3 Tahun 10Bulan \\
\hline duster2 & 2 & SMA & 2 & Sumatra & 84 & 455 & 3,22 & 5Tahun \\
\hline cluster 3 & 1 & SMA & 2 & Sumatra & 78 & 423 & 3,31 & 6Tahun \\
\hline
\end{tabular}

Hasil dari evaluasi pola pada dataset Industri dengan jumlah cluster 4, maka diperoleh cluster 1 sebagai cluster yang terbaik untuk rekomendasi lulus tepat waktu, jika nilai rata-rata matematika 84, berasal dari pulau Jawa, dan rata-rata IPK sebesar 3,56 .

\section{d. Dataset Elektro}

Pada dataset Elektro dengan jumlah data 30, diperoleh pengujian yang disajikan pada Tabel XXI.

TABEL XXI. Hasil Pengujian Dataset Elektro

\begin{tabular}{|c|c|}
\hline Nilai K (Jumlah Titik Pusat ) & Hasil Silhouette Coefficient \\
\hline 2 & 0,602 \\
\hline 3 & 0,879 \\
\hline 4 & 0,768 \\
\hline 5 & 0,686 \\
\hline 6 & 0,716 \\
\hline 7 & 0,458 \\
\hline 8 & 0,325 \\
\hline
\end{tabular}

Berdasarkan hasil pengujian pada dataset Elektro dapat ditarik kesimpulan bahwa pada dataset Industri jumlah cluster terbaik yaitu 3. Sehingga diperoleh 3 cluster dengan evaluasi pola setiap cluster sebagai berikut :
TABEL XXII. HASIL CLUSTER ElEKTRO

\begin{tabular}{|c|c|c|c|c|c|c|c|c|}
\hline Nilaik & Dota & Asal Sekolah & Wilaygh & Pulau & Rata MTK & TOEEL & PR & Lamms Studi \\
\hline cluster 0 & 10 & SMA \& SWK & 2 & Sumatra & 74 & 435 & 3,23 & 4Tahun ABulan \\
\hline cluster1 & 1 & SMA & 2 & Jawa & 80 & 43 & 3,31 & 5Thun \\
\hline cluster? & 19 & SMA \& SMK & 2 & Jawa & 80 & 421 & 3,56 & 3Tahun10Bulan \\
\hline
\end{tabular}

Hasil dari evaluasi pola pada dataset Elektro dengan jumlah cluster 3 , maka diperoleh cluster 1 sebagai cluster yang terbaik untuk rekomendasi lulus tepat waktu, jika nilai rata-rata matematika 80, berasal dari pulau Jawa, dan rata-rata IPK sebesar 3,56 .

\section{KesIMPULAN DAN SARAN}

\subsection{Kesimpulan}

Berdasarkan penelitian "Penerapan Data Mining Dalam Mengelompokkan Data Riwayat Akademik Sebelum Kuliah dan Data Kelulusan Mahasiswa Menggunakan Metode Agglomerative Hierarchical Clustering" dapat ditarik kesimpulan sebagai berikut :

a. Penelitian menghasilkan 158 data mahasiswa

yang di rekomendasikan dari keseluruhan dataset yang terdiri dari beberapa data :

1. Rekomendasi prodi Informatika jumlah data sebanyak 43 data dan mayoritas berasal dari SMA, Asal wilayah 2, pulau Jawa, serta memiliki rata-rata nilai matematika sebesar 80, TOEFL sebesar 424, IPK sebesar 3,50 dengan lama studi yaitu 3 tahun 9 bulan.

2. Rekomendasi prodi Kimia jumlah data sebanyak 72 data dan mayoritas berasal dari SMA, Asal wilayah 2, pulau Jawa, serta memiliki rata-rata nilai matematika sebesar 67, TOEFL sebesar 438, IPK sebesar 3,53 dengan lama studi yaitu 3 tahun 9 bulan.

3. Rekomendasi prodi Industri jumlah data sebanyak 24 data dan mayoritas berasal dari SMA, Asal wilayah 2, pulau Jawa, serta memiliki rata-rata nilai matematika sebesar 84, TOEFL sebesar 423, IPK sebesar 3,56 dengan lama studi yaitu 3 tahun 10 bulan.

4. Rekomendasi prodi Elektro jumlah data sebanyak 19 data dan berasal dari SMA dan SMK berjumlah sama, Asal wilayah 2, pulau Jawa, serta memiliki rata-rata nilai matematika sebesar 80, TOEFL sebesar 421, IPK sebesar 3,56 dengan lama studi 3 tahun 10 bulan.

b. Hasil pengujian pada aplikasi "Penerapan Data Mining Dalam Mengelompokkan Data Riwayat 
Akademik Sebelum Kuliah dan Data Kelulusan Mahasiswa Menggunakan Metode Agglomerative Hierarchical Clustering" dan menggunakan pengujian hasil cluster dengan Silhouette Coefficient memperoleh hasil yang sangat bagus dengan nilai silhouette coefficient untuk dataset prodi Informatika sebesar 0,868, untuk dataset prodi Kimia sebesar 0,873, untuk dataset prodi Industri sebesar 0,883 , dan untuk dataset prodi Elektro sebesar 0,879.

\subsection{Saran}

Beberapa saran yang dapat dijadikan landasan untuk pengembangan dan perbaikan untuk menutupi kekurangan dan kelemahan dari penelitian ini, sebagai berikut :

a. Menggunakan dataset yang lebih banyak dan menambahkan variabel atau atribut yang dapat menghasilkan pengelompokan yang lebih akurat.

b. Menggunakan beberapa metode pengelompokan Agglomerative Hierarchical lainnya seperti : Complete Linkage dan Average Linkage.

\section{DAFTAR PUSTAKA}

[1] T. Suprawoto, "Klasifikasi Data Mahasiswa Menggunakan Metode K-Means Untuk Menunjang Pemilihan Strategi Pemasaran," JIKO (Jurnal Inform. dan Komputer), vol. 1, no. 1, pp. 12-18, 2016, doi: 10.26798/jiko.2016.v1i1.9.

[2] N. Syahid, "Tahun 2019 'Lulusan Tepat Waktu Mahasiswa FTI UAD Angkatan 2015 Sebanyak 22\%,'” 2019. https://fti.uad.ac.id/lulusan-tepatwaktu-mahasiswa-fti-uad-angkatan-2015sebanyak-22/.

[3] J. F. Ulysses, "Data Mining Classification Untuk
Prediksi Lama Masa Studi Mahasiswa Berdasarkan Jalur Penerimaan Dengan Metode Naive Bayes," no. 125301917, pp. 1-8, 2008.

[4] F. Nasari and S. Darma, "Seminar Nasional Teknologi Informasi dan Multimedia 2015 Penerapan K-Means Clustering Pada Data Penerimaan Mahasiswa Baru (Studi Kasus: Universitas Potensi Utama)," pp. 6-8, 2015.

[5] H. Februariyanti and D. B. Santoso, "Hierarchical Agglomerative Clustering Untuk Pengelompokan Skripsi Mahasiswa," Pattern Recognit., 2017, doi: 10.1016/0031-3203(79)90049-9.

[6] J. A. S. Almeida, L. M. S. Barbosa, A. A. C. C. Pais, and S. J. Formosinho, "Improving hierarchical cluster analysis: A new method with outlier detection and automatic clustering," Chemom. Intell. Lab. Syst., vol. 87, no. 2, pp. 208-217, 2007, doi: 10.1016/j.chemolab.2007.01.005.

[7] R. Helilintar, I. N. Farida, and R. H. Irawan, "Penerapan Metode K-Means Clustering Pada Data Penerimaan Mahasiswa Baru," pp. 14-20, 2018.

[8] Y. Palumpun and S. N. Alam, "Pengelompokan Tingkat Kelulusan Mahasiswa Menggunakan Algoritma K-Means," no. November, pp. 98-102, 2017.

[9] R. Rosmini, A. Fadlil, and S. Sunardi, "Implementasi Metode K-Means Dalam Pemetaan Kelompok Mahasiswa Melalui Data Aktivitas Kuliah," It J. Res. Dev., vol. 3, no. 1, p. 22, 2018, doi: 10.25299/itjrd.2018.vol3(1).1773.

[10] G. S. Nugraha and H. Hairani, "Aplikasi Pemetaan Kualitas Pendidikan di Indonesia Menggunakan Metode K-Means," J. MATRIK, vol. 17, no. 2, pp. 13-23, 2018, doi: 10.30812/matrik.v17i2.84.

[11] M. DelSole, "What is One Hot Encoding and How to Do It," 2018. https://medium.com/@michaeldelsole/what-isone-hot-encoding-and-how-to-do-it-f0ae272f1179 (accessed Dec. 13, 2019). 